\title{
Gibberellic Acid Promotes Early Growth of Winter Wheat and Rye
}

\author{
Alexander D. Pavlista1 ${ }^{*}$, David D. Baltensperger ${ }^{2}$, Dipak K. Santra1 ${ }^{1}$, Gary W. Hergert ${ }^{1}$, \\ Steve Knox ${ }^{3}$ \\ ${ }^{1}$ Department of Agronomy and Horticulture, University of Nebraska, Panhandle Research \& Extension Center, \\ Scottsbluff, NE, USA \\ ${ }^{2}$ Department of Soil and Crop Sciences, Texas A\&M University, College Station, TX, USA \\ ${ }^{3}$ Nebraska Crop Improvement Association, Lincoln, NE, USA \\ Email: ${ }^{*}$ apavlista@unl.edu
}

Received 1 July 2014; revised 9 August 2014; accepted 4 September 2014

Copyright (C) 2014 by authors and Scientific Research Publishing Inc.

This work is licensed under the Creative Commons Attribution International License (CC BY).

http://creativecommons.org/licenses/by/4.0/

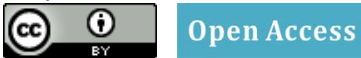

\begin{abstract}
Winter wheat (Triticum aestivum) planting in Nebraska is recommended for mid Sep but summer crops are often harvested around Oct 1 . Also, weather may delay planting. Could gibberellic acid $\left(\mathrm{GA}_{3}\right)$, a growth stimulant, overcome the delayed seedling growth from late planting? Irrigated field trials were planted from 2005 to 2010 applying $\mathrm{GA}_{3}$ to wheat seed of cvs. Goodstreak and Wesley. In 2005, dip, spray and furrow $\mathrm{GA}_{3}$ applications to seed were tested. Dip and spray gave similar results. Furrow application was calculated too costly. Further tests used seed dips. In 2006 to 2008 planting, wheat was planted about 15 Sep, 1 Oct and 15 Oct. Trials planted in 2007 and 2008 included winter rye (Secale cereale) cv. Rymin. Heights in mid Nov showed a reduction with later planting. When planted about 1 0ct and $150 \mathrm{ct}$, the delayed growth of Goodstreak, compared to planting two weeks earlier, was fully overcome by $\mathrm{GA}_{3}$ at $250 \mathrm{ppm}$. For Wesley, $1000 \mathrm{ppm} \mathrm{GA}$ was needed to nearly overcome later planting. Rymin rye gave an intermediate response between the two wheat cultivars. Spring and summer heights were not affected by $\mathrm{GA}_{3}$. Spring biomass, yield and harvested seed germination showed no $\mathrm{GA}_{3}$ effect. In later trials (planted in 2009 and 2010), the cytokinin 6-benzyl adenine (6BA) was added to $\mathrm{GA}_{3}$ to stimulate tiller formation. In the $1^{\text {st }}$ year, 6BA at $2000 \mathrm{ppm}$ depressed height, weight and yield without tiller promotion. Repeating the trial with lower rates $(31-125 \mathrm{ppm} 6 \mathrm{BA})$ did not offer an additional advantage to $\mathrm{GA}_{3}$. The results indicate that seed application of $\mathrm{GA}_{3}$ can overcome delayed growth resulting from delayed planting of winter wheat and rye under irrigation. This procedure is recommended and is being used by growers who report satisfaction from the benefit and low cost, $<$ US\$ $3.00 \mathrm{ha}^{-1}$.
\end{abstract}

\footnotetext{
"Corresponding author.
}

How to cite this paper: Pavlista, A.D., Baltensperger, D.D., Santra, D.K., Hergert, G.W. and Knox, S. (2014) Gibberellic Acid Promotes Early Growth of Winter Wheat and Rye. American Journal of Plant Sciences, 5, 2984-2996. 


\section{Keywords}

\section{Plant Growth Regulator, Gibberellin, Planting Aid, Wind Erosion, Soil Erosion, Cover Crop, Crop Rotation}

\section{Introduction}

The desired planting date for winter wheat in Nebraska is around 15 September [1]. However, many summer crops, e.g., dry bean (Phaseolus vulgaris) and potato (Solanum tuberosum) grown in the state and region are rotated with wheat and are harvested normally in late Sep and early Oct [2] [3]. Stimulating seedling growth of wheat planted later to make up for a two-week delayed planting would allow later planting [4] and establish the crop for protection against wind erosion of soil [5]. This would make winter wheat and summer crops more compatible.

Gibberellin, first identified from a pathogenic fungus [6], is a family of natural growth promoters of which $\mathrm{GA}_{3}$ may be the most active in stimulating stem elongation [7]. Recently, GA 3 bioassays for stem growth were reported on common bean [8] and winter wheat [9] demonstrating differential sensitivity of cultivars and growth habits. In wheat, popular cultivars in irrigated production are semi-dwarf and tend to be less sensitive to GA then non-semi-dwarf or tall cultivars [10] [11]. Therefore to identify relative effects of $\mathrm{GA}_{3}$ on these two types of winter wheat, the cultivars Goodstreak [12], a tall type, and Wesley [13], a semi-dwarf type, were field tested using the rate guidelines reported from growth chamber tests [9].

Wheat height genetics is complex and determined by many Rht ("Reduced Height") genes. Depending on their reaction to exogenous $\mathrm{GA}_{3}$, the $R$ ht genes are classified into two groups, $\mathrm{GA}_{3}$-sensitive (synthesis mutants) and $\mathrm{GA}_{3}$-insensitive [14]. Dwarfism in wheat lines carrying $\mathrm{GA}_{3}$-sensitive genes is due to either the absence of or a modified spectrum of endogenous gibberellin. These genes are involved in $\mathrm{GA}_{3}$ biosynthesis and normal growth can be restored by exogenous $\mathrm{GA}_{3}$. Goodstreak and Wesley are hard red winter wheat cultivars adapted to the region around western Nebraska [12] [13]. Goodstreak grows to a conventional height ("tall") and has a long coleoptile. Wesley is a semi-dwarf, about 15\% shorter than Goodstreak, with a short coleoptile and carries the $\mathrm{GA}_{3}$-sensitive gene Rht8c (Rht8) in addition to the $\mathrm{GA}_{3}$-insensitive gene $R h t-B 1 b(R h t 1)$. Rht8c is agronomically the most important dwarfing gene for many wheat cultivars [15]. Semi-dwarf cultivars, e.g., Wesley, may emerge erratically when planted late or in dry soil [4]. Goodstreak and Wesley are excellent for comparing conventional and semi-dwarf cultivars for their sensitivity to seed-applied $\mathrm{GA}_{3}$ in a field environment.

Another aspect is to stimulate seedling growth of a grass cover crop to resist wind erosion during the winter followed by planting a summer crop such as potato. Winter rye is used as a cover crop [16] and for pasture [17]. Similar to wheat, rye may have dwarf genes related to $\mathrm{GA}_{3}$ mutants [14]. The cultivar Rymin is a medium tall type [18].

The main objective of this study was to hasten fall growth of irrigated winter wheat when planted later than recommended using $\mathrm{GA}_{3}$ for improved pre-winter seedling establishment. The second objective was to determine whether there were long-lasting negative effects of $\mathrm{GA}_{3}$ into the spring and summer. A third objective was to determine whether the addition of 6BA, a cell division promoter (cytokinin) [7], to GA $\mathrm{G}_{3}$ would promote tiller production. In addition to winter wheat, the response of winter rye to $\mathrm{GA}_{3}$ at different planting dates was included in two trials.

\section{Materials and Methods}

\subsection{Trial Conditions}

Between 2005 and 2011, field trials were conducted on winter wheat (Triticum aestivum L.) cultivars Goodstreak [12] and Wesley [13] and between 2007 and 2009, on winter rye (Secale cereale L.) cultivar Rymin [18] at the Univ. of Nebraska’s Panhandle Research \& Extension Center, Scottsbluff (lat. 41.9N, long. 103.7W, elevation $1208 \mathrm{~m}$ ). Soil was a Tripp fine sandy loam at pH 7.8 - 8.1 and organic matter content of $0.7 \%-1.0 \%$. Rainfall and temperature were monitored by the High Plains Regional Climate Center [19]. Trials were conducted under an overhead, linear-move irrigation system applying 9 to $11 \mathrm{~cm}$ water in May and June supple- 
menting rainfall for a total of about $25 \mathrm{~cm}$. Mean temperatures for May and June were between $15.7^{\circ} \mathrm{C}$ and $18.5^{\circ} \mathrm{C}$. Fertilizer was applied in mid Sep as ammonium nitrate in 2005 and 2006, and as ammonium sulfate plus mono-ammonium phosphate later. Total $\mathrm{N}$ was about $200 \mathrm{~kg} \cdot \mathrm{ha}^{-1}$. Fields were cleaned of weeds with glyphosate applied in early Sep before first planting. In April, 2,4-D was applied for weed control as appropriate. Geese feeding was deterred by using flash tape attached to poles spaced every $6 \mathrm{~m}$ from December to April. All plots in all trials were four rows with spacing of $30 \mathrm{~cm}$. Harvested row length was $6.1 \mathrm{~m}$ of $7.6 \mathrm{~m}$ planted with the exception of the furrow-application trial in 2005 where the row length was $12.2 \mathrm{~m}$ of $15.2 \mathrm{~m}$ planted. The targeted seeding rate was 330 seeds $\mathrm{m}^{-2}$. To accomplish this target, each year, 100-seed samples of Goodstreak and Wesley were weighed and averaged to calculate weight per seed. The seed weight per plot was calculated in order to achieve 2700 - 2800 seeds per plot. In the furrow trial in 2005, the calculation per plot was adjusted for the longer row length. Planting dates were grouped into three periods: $1^{\text {st }}$ planting in mid Sep (14 to 20), $2^{\text {nd }}$ about 1 Oct (28 Sep to 4 Oct), and $3^{\text {rd }}$ in mid Oct (12 to 19). A 12 to 14 day interval was maintained between planting dates in a given year. Harvesting was in the second half of July the following year.

\subsection{Chemical Preparation and Applications}

Gibberellic acid $\left(\mathrm{GA}_{3}\right)$ was applied as Release LC, a $4 \%$ a.i. by weight formulation, i.e., $1 \mathrm{~g} \mathrm{GA}_{3} / 30 \mathrm{~mL}$, formulation (Valent BioScience Corp., Long Grove, IL). Release LC was serially diluted with water to achieve desired concentrations. In 2009 and 2010, 6-benzyl adenine (6BA) as MaxCel, a 1.9\% a.i. by weight formulation (Valent Bioscience) was added to $\mathrm{GA}_{3}$. For seed dip treatments used in all years, sufficient seed was weighed to plant 20 plots and treat with $1 \mathrm{~L}$ of water, $\mathrm{GA}_{3}$ solution, or $\mathrm{GA}_{3}+6 \mathrm{BA}$ solution. For planting in 2006, 2007 and 2008, Goodstreak seed weight was $1.1 \mathrm{~kg} / 20$ plots (about 55,000 seeds); for Wesley, it was $1.6 \mathrm{~kg} / 20$ plots, and for Rymin rye, it was $1.2 \mathrm{~kg} / 20$ plots. Wheat seed weight for 20 plots in 2005, 2009 and 2010 was about $1.6 \mathrm{~kg}$ for Goodstreak and about $2.1 \mathrm{~kg}$ for Wesley. The 20-plot seed samples were placed in 4-L Erlenmeyer flasks followed by the treatment solution. The solution and seeds were mixed through rapid shaking and inversion of the flasks for two minutes. Afterwards, the flask was drained of liquid using a sieve to hold the seeds. The seeds were, then, layered on an aluminum tray for air drying with periodic stirring over the next few days. In 2005, for the seed spray, $728 \mathrm{~g}$ of Wesley seed, sufficient for 7 plots, was placed on a plastic sheet. Solutions were placed in spray bottles and $200 \mathrm{~mL}$ was sprayed using a $\mathrm{CO}_{2}$ backpack sprayer. After treatment, seeds were removed from the plastic, placed in aluminum trays and air dried. The third application method tested in 2005 was planting Wesley seed into open furrows in the field, followed by spraying the treatment solutions onto the seed with a $\mathrm{CO}_{2}$ backpack sprayer, and then covering up the seed in the furrow. The experiment breakdown by year is summarized in Table 1.

Table 1. Experiment summary by year.

\begin{tabular}{|c|c|c|c|c|}
\hline Year planted & Experiment & Cultivar $^{1}$ & Application & Treatment $^{2} \&$ Rates \\
\hline \multirow[t]{3}{*}{2005} & Planting date ${ }^{3}$ & Goodstreak and Wesley & Seed $\operatorname{dip}^{4}$ & GA 31000 ppm \\
\hline & Seed treatment & Wesley & Seed dip, seed spray ${ }^{5}$ & GA $3 @ 500,2000,4000$ ppm \\
\hline & Furrow & Wesley & Furrow spray ${ }^{6}$ & $\mathrm{GA}_{3} @ 175,350,700,1400 \mathrm{~g} \cdot \mathrm{ha}^{-1}$ \\
\hline $\begin{array}{l}2006 \\
2007 \\
2008\end{array}$ & Planting date & Goodstreak and Wesley & Seed dip & $\mathrm{GA}_{3} @ 125,250,500,1000$ ppm \\
\hline $\begin{array}{l}2007 \\
2008\end{array}$ & Planting date & Rymin rye & Seed dip & GA $3 @ 125,250,500,1000$ ppm \\
\hline \multirow[t]{2}{*}{2009} & Cytokinin added & Goodstreak & Seed dip & GA $@ 500$ ppm+6BA @ 0, 125, 500, 2000 ppm \\
\hline & & Wesley & Seed dip & GA $@ 1000$ ppm+6BA @ 0, 31, 63, 125 ppm \\
\hline \multirow[t]{2}{*}{2010} & Cytokinin added & Goodstreak & Seed dip & GA @ $_{3} 250$ ppm+6BA @ 0, 31, 63, 125 ppm \\
\hline & & Wesley & Seed dip & GA $@ 500$ ppm +6BA@ 0, 125, 500, 2000 ppm \\
\hline
\end{tabular}

${ }^{1}$ Goodstreak and Wesley are winter wheat cultivars; Rymin is a winter rye cultivar. ${ }^{2}$ Water was included in all trials as check. ${ }^{3}$ Planting dates were mid Sep, about 1 Oct and mid Oct. ${ }^{4}$ Seeds for 20 plots were exposed to $1000 \mathrm{~mL}$ of treatment for 2 min then drained and air dried. ${ }^{5}$ Seeds for 7 plots were sprayed with $200 \mathrm{~mL}$ of treatment then removed and air dried. ${ }^{6}$ Untreated seeds were planted into an open furrow onto which water or GA $\mathrm{A}_{3}$ was sprayed using a $\mathrm{CO}_{2}$ sprayer set to apply $94 \mathrm{~L} \cdot \mathrm{ha}^{-1}$ carrier and then the furrow was covered. 


\subsection{Data Collection and Analysis}

Heights were measured from the ground or base to the tip of the longest leaf between 12 and 20 Nov prior to the onset of winter, between 20 Mar and 8 Apr, between 7 and 22 May, and in July prior to harvest. Biomass was measured in May by removing upper potion of plants from $0.91 \mathrm{~m}$ of two rows $\left(0.56 \mathrm{~m}^{2}\right)$ from each plot, weighing samples for fresh weight and after several days in a plant dryer, weighing for dry weight of same samples. Plots were harvested directly and grain weighed between 12 and 28 Jul. Grain fresh and dry weights were measured and yields were adjusted to $12.5 \%$ moisture. Germination percentages of wheat seeds from samples harvested in 2007, 2008 and 2009, from trials planted in 2006, 2007 and 2008, were determined using a standardized method [20]. In 2005, the planting date experiment consisted of 12 treatments in 6 replications in an RCBD; the seed treatment experiment was 8 treatments replicated 6 times in an RCBD, and the furrow experiment contained 5 treatments in 5 replications in an RCBD. In all other trials (planted 2006 to 2010), the cultivars were tested separately and could not be directly compared. Each trial consisted of main plots based on five GA 3 rates (2006, 2007, 2008) or five GA $_{3}$-6BA treatments $(2009,2010)$ in Latin Square designs with 5 replications. Each main plot was split into three strips, each at one of the three planting dates (mid Sep, about 1 Oct, mid Oct). Data from each trial were analyzed separately, except when years were combined, using SAS Proc ANOVA. Treatment means were separated using least significant differences (SAS Institute).

\section{Results}

\subsection{GA 3 Application Method and Rate Response (2005)}

Planted in 2005, an initial field test was conducted to determine whether applying $\mathrm{GA}_{3}$ to seed of cultivars Goodstreak and Wesley would affect early seedling growth of late-planted seed. Heights measured in mid Nov showed that dipping seeds for a short time in 1000 ppm GA 3 significantly increased the heights of both cultivars when planting was 2 and 4 weeks later than the mid Sep recommendation for the Nebraska Panhandle (Table 2). When planted at the recommended date, $\mathrm{GA}_{3}$ did not affect seedling height. Untreated seedlings resulting from later planting as expected were smaller being younger (Table 2). The measurements showed that applying GA to seed was able to compensate for the loss of growing time. This was significant with "Goodstreak" where the

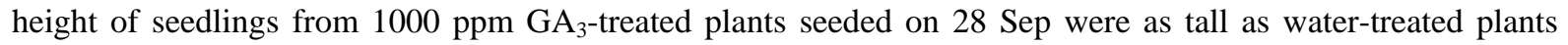
seeded two weeks earlier (Table 2). Likewise, $\mathrm{GA}_{3}$-treated plants seeded on 12 Oct were as tall as the checks seeded on 28 Sep. With Wesley where $\mathrm{GA}_{3}$ treatment significantly promotes height, the promotion was not sufficient to overcome the two-week delay in seeding (Table 2). Although there were height differences between planting dates and cultivars, the $\mathrm{GA}_{3}$-induced promotion of height did not last through the winter and spring as there was no difference between treated and check plants (Table 2). GA 3 had no effect on lodging of Goodstreak. Although there was a significant difference in yield between the two cultivars, there was no $\mathrm{GA}_{3}$ or planting date effect except for the last planting of Wesley (Table 2). Seed treatments with $\mathrm{GA}_{3}$ using a 1 to 2 min dip or a directed spray were compared on Wesley in 2005. Application of 500 ppm GA 3 as a seed dip increased height in November (Table 3). When $\mathrm{GA}_{3}$ was applied as a spray onto seed, significant height promotion in Nov was measured with 4000 ppm. GA 3 did not affect post winter height or yield (Table 3). However, there was no difference between the seed treatment methods comparing each $\mathrm{GA}_{3}$ rate. Another method to expose seeds to GA is to spray the material during planting into the open furrow on and around the seed. Table 4 showed that application of $700 \mathrm{~g} \cdot \mathrm{ha}^{-1}$ (7500 ppm GA ) would be needed to increase pre winter seedling height of Wesley.

\subsection{Planting Date and $\mathrm{GA}_{3}$ Rate Response $(2006,2007,2008)$}

Field trials in 2006, 2007 and 2008 compared the seed dip application of $\mathrm{GA}_{3}$ at different rates and planting at different dates on Goodstreak and Wesley. Across years, $\mathrm{GA}_{3}$ applied at 500 ppm to Goodstreak and planted in mid Sep significantly increased seedling height measured in Nov (Table 5). When planted later, however, less $\mathrm{GA}_{3}(125$ - $250 \mathrm{ppm})$ stimulated growth of Goodstreak. In Wesley, height was increased by 1000 ppm GA 3 in two of three years and by 250 ppm in 2006 (Table 5). Both later planting dates showed height increases by 250 ppm $\mathrm{GA}_{3}$ in all years. The height of seedlings for both cultivars was lowered with later planting. Adding 250 ppm $\mathrm{GA}_{3}$ to Goodstreak allowed seedlings planted in early October to attain the same growth as untreated

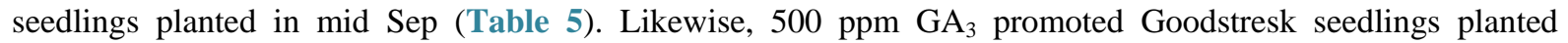


Table 2. Plant height, lodging and yield of winter wheat cultivars Goodstreak and Wesley planted at three dates with seed dipped in water or gibberellic acid $\left(\mathrm{GA}_{3}\right)$ at $1000 \mathrm{ppm}$, 2005-2006.

\begin{tabular}{|c|c|c|c|c|c|c|c|}
\hline & \multirow[b]{2}{*}{ Planting } & \multirow[b]{2}{*}{$\mathrm{GA}_{3}{ }^{3}$} & \multicolumn{3}{|c|}{ Plant height ${ }^{1}$} & \multirow{2}{*}{\begin{tabular}{|c|} 
Lodging \\
30 Jun 06
\end{tabular}} & \multirow{2}{*}{$\begin{array}{c}\text { Yield }^{2} \\
\text { 14 Jul } 06\end{array}$} \\
\hline & & & 17 Nov 05 & 24 May 06 & 30 Jun 06 & & \\
\hline Cultivar & Date & $\mathrm{ppm}^{4}$ & & $\mathrm{~cm}$ & & $\%$ & $\mathrm{mg} \cdot \mathrm{ha}^{-1}$ \\
\hline \multirow[t]{6}{*}{ Goodstreak } & 14 Sep 05 & 0 & $16.2 \mathrm{~B}^{5}$ & $102 \mathrm{~A}$ & $106 \mathrm{~A}$ & $83 \mathrm{~A}$ & $5.17 \mathrm{D}$ \\
\hline & & 1000 & $16.7 \mathrm{AB}$ & $100 \mathrm{~A}$ & $103 \mathrm{AB}$ & $87 \mathrm{~A}$ & $5.00 \mathrm{D}$ \\
\hline & 28 Sep 05 & 0 & $10.8 \mathrm{D}$ & $95 \mathrm{~B}$ & $103 \mathrm{AB}$ & $83 \mathrm{~A}$ & $5.19 \mathrm{D}$ \\
\hline & & 1000 & $17.9 \mathrm{~A}$ & $94 \mathrm{~B}$ & $105 \mathrm{~A}$ & $79 \mathrm{~A}$ & $5.16 \mathrm{D}$ \\
\hline & 12 Oct 05 & 0 & $6.9 \mathrm{E}$ & $86 \mathrm{D}$ & $102 \mathrm{AB}$ & $0 \mathrm{~B}$ & $6.03 \mathrm{D}$ \\
\hline & & 1000 & $10.9 \mathrm{D}$ & $83 \mathrm{D}$ & $100 \mathrm{~B}$ & $4 \mathrm{~B}$ & $5.94 \mathrm{D}$ \\
\hline \multirow[t]{6}{*}{ Wesley } & 14 Sep 05 & 0 & $17.5 \mathrm{~A}$ & $90 \mathrm{C}$ & $94 \mathrm{C}$ & $12 \mathrm{~B}$ & $9.18 \mathrm{~A}$ \\
\hline & & 1000 & $16.8 \mathrm{AB}$ & $90 \mathrm{C}$ & $91 \mathrm{C}$ & $13 \mathrm{~B}$ & $9.48 \mathrm{~A}$ \\
\hline & 28 Sep 05 & 0 & $12.6 \mathrm{C}$ & $86 \mathrm{D}$ & $89 \mathrm{C}$ & $4 \mathrm{~B}$ & $8.63 \mathrm{AB}$ \\
\hline & & 1000 & $16.2 \mathrm{~B}$ & $86 \mathrm{D}$ & $89 \mathrm{C}$ & $8 \mathrm{~B}$ & $9.08 \mathrm{AB}$ \\
\hline & 12 Oct 05 & 0 & $7.1 \mathrm{E}$ & $74 \mathrm{E}$ & $81 \mathrm{D}$ & $0 \mathrm{~B}$ & $8.04 \mathrm{BC}$ \\
\hline & & 1000 & $9.8 \mathrm{D}$ & $72 \mathrm{E}$ & $80 \mathrm{D}$ & $4 \mathrm{~B}$ & $7.46 \mathrm{C}$ \\
\hline \multicolumn{3}{|c|}{$\mathrm{GA}_{3}$ seed treatment $(\mathrm{G})$} & $* * * 6$ & ns & ns & ns & ns \\
\hline \multicolumn{3}{|c|}{ Planting date (P) } & $* * *$ & $* * *$ & $* * *$ & $* * *$ & ns \\
\hline \multicolumn{3}{|c|}{ Cultivar (C) } & ns & *** & $* * *$ & *** & $* * *$ \\
\hline \multicolumn{3}{|c|}{$\mathrm{G}^{*} \mathrm{P}$} & *** & ns & ns & ns & ns \\
\hline \multicolumn{3}{|c|}{$\mathrm{G}^{*} \mathrm{C}$} & ${ }^{* *}$ & ns & ns & ns & ns \\
\hline \multicolumn{3}{|c|}{$\mathrm{P}^{*} \mathrm{C}$} & ns & ns & ** & *** & $* * *$ \\
\hline \multicolumn{3}{|c|}{$\mathrm{G}^{*} \mathrm{P}^{*} \mathrm{C}$} & ns & ns & ns & ns & ns \\
\hline
\end{tabular}

${ }^{1}$ Seeds were dipped in water or $1000 \mathrm{ppm} \mathrm{GA}$ for 1 to $2 \mathrm{~min}$, air-dried for a week, and then planted. ${ }^{2}$ Plant height was measured from ground to the highest leaf tip. ${ }^{3}$ Yield was adjusted to $12.5 \%$ kernel moisture. ${ }^{4} 1$ inch $=2.54 \mathrm{~cm}, 1 \mathrm{lb} \cdot \mathrm{a}^{-1}=1.1209 \mathrm{~kg} \cdot \mathrm{ha}{ }^{-1}, 1 \mathrm{ppm}=1 \mathrm{mg} \cdot \mathrm{L}^{-1}$. ${ }^{5} \mathrm{Mean} \mathrm{separation} \mathrm{for}$ each column using least significant difference at $P<0.05 .{ }^{6} \mathrm{~ns}=$ not significant at $P<0.05 ;{ }^{*},{ }^{* *},{ }^{* * *}=$ significant at $P<0.05, P<0.01$, and $P<0.001$, respectively.

Table 3. Plant height and yield of winter wheat cultivar Wesley planted on 28 Sep 05 with seed treated with water or gibberellic acid $\left(\mathrm{GA}_{3}\right)$ by dip or spray ${ }^{1}, 2005-06$.

\begin{tabular}{|c|c|c|c|c|c|}
\hline \multirow{3}{*}{$\begin{array}{c}\text { Application } \\
\text { method }\end{array}$} & \multirow{3}{*}{$\begin{array}{l}\mathrm{GA}_{3}{ }^{1} \\
\mathrm{ppm}^{4}\end{array}$} & \multicolumn{3}{|c|}{ Plant height ${ }^{2}$} & \multirow{3}{*}{$\begin{array}{c}\text { Yield }^{3} \\
\text { 14 Jul } 06 \\
\mathrm{mg} \cdot \mathrm{ha}^{-1}\end{array}$} \\
\hline & & 17 Nov 05 & 24 May 06 & 14 Jul 06 & \\
\hline & & & $\mathrm{cm}$ & & \\
\hline \multirow[t]{4}{*}{ Seed dip } & 0 & $14.0 C^{5}$ & 77 & 91 & 9.58 \\
\hline & 500 & $17.5 \mathrm{AB}$ & 77 & 90 & 9.78 \\
\hline & 2000 & $19.0 \mathrm{~A}$ & 78 & 90 & 9.42 \\
\hline & 4000 & $17.5 \mathrm{AB}$ & 77 & 90 & 9.41 \\
\hline \multirow[t]{4}{*}{ Seed spray } & 0 & $15.0 \mathrm{BC}$ & 79 & 91 & 9.59 \\
\hline & 500 & $17.8 \mathrm{AB}$ & 77 & 90 & 9.57 \\
\hline & 2000 & $17.8 \mathrm{AB}$ & 80 & 90 & 9.12 \\
\hline & 4000 & $19.2 \mathrm{~A}$ & 77 & 90 & 9.59 \\
\hline \multicolumn{2}{|c|}{$\mathrm{GA}_{3}$ rate $(\mathrm{G})$} & $* * 6$ & ns & ns & ns \\
\hline \multicolumn{2}{|c|}{ Seed application (A) } & ns & ns & ns & ns \\
\hline \multicolumn{2}{|c|}{$\mathrm{G}^{*} \mathrm{~A}$} & ns & ns & ns & ns \\
\hline
\end{tabular}

${ }^{1}$ Seeds were dipped for 1 to 2 min or coated using a $\mathrm{CO}_{2}$ sprayer, drained, air-dried for a week, and then planted. ${ }^{2} \mathrm{Plant}$ height was measured from ground to the highest leaf tip. ${ }^{3}$ Yield was adjusted to $12.5 \%$ kernel moisture. ${ }^{4} 1 \mathrm{inch}=2.54 \mathrm{~cm}, 1 \mathrm{lb} \cdot \mathrm{a}^{-1}=1.1209 \mathrm{~kg} \cdot \mathrm{ha}{ }^{-1}, 1 \mathrm{ppm}=1 \mathrm{mg} \cdot \mathrm{L}^{-1}$. ${ }^{5} \mathrm{Mean}$ separation for each column using least significant difference at $P<0.05$. ${ }^{6} \mathrm{~ns}=$ not significant at $P<0.05$; $^{*},{ }^{* * *},{ }^{* * *}=$ significant at $P<0.05, P<0.01$, and $P<0.001$, respectively. 
Table 4. Plant height and yield of winter wheat cultivar Wesley planted on 28 Sep 05 with water or gibberellic acid (GA 3 ) applied into an open furrow onto seeds ${ }^{1}, 2005-06$.

\begin{tabular}{|c|c|c|c|c|c|}
\hline & & & Plant height ${ }^{2}$ & & Yield $^{3}$ \\
\hline $\begin{array}{c}\text { Application } \\
\text { method }\end{array}$ & $\begin{array}{c}\mathrm{GA}_{3}{ }^{1} \\
\mathrm{~g} \cdot \mathrm{ha}^{-14}\end{array}$ & 17 Nov 05 & $\begin{array}{c}24 \text { May } 06 \\
\text { cm }\end{array}$ & $14 \mathrm{Jul} 06$ & $\begin{array}{l}14 \mathrm{Jul} 06 \\
\mathrm{mg} \cdot \mathrm{ha}^{-1}\end{array}$ \\
\hline \multirow[t]{5}{*}{ Furrow } & 0 & $13.6 \mathrm{~B}^{5}$ & 73 & 88 & 8.81 \\
\hline & 175 & $13.4 \mathrm{~B}$ & 74 & 87 & 8.35 \\
\hline & 350 & $14.4 \mathrm{AB}$ & 75 & 87 & 8.19 \\
\hline & 700 & $16.7 \mathrm{~A}$ & 74 & 88 & 8.62 \\
\hline & 1400 & $14.8 \mathrm{AB}$ & 73 & 88 & 8.30 \\
\hline
\end{tabular}

${ }^{1}$ Untreated seeds were planted into an open furrow onto which water or $\mathrm{GA}_{3}$ was sprayed using a $\mathrm{CO}_{2}$ sprayer set to apply $94 \mathrm{~L} \cdot$ ha ${ }^{-1}$ carrier and then the furrow was covered. ${ }^{2}$ Plant height was measured from ground to the highest leaf tip. ${ }^{3}$ Yield was adjusted to $12.5 \%$ kernel moisture. ${ }^{4} 1$ inch $=2.54$ $\mathrm{cm}, 1 \mathrm{lb} \cdot \mathrm{a}^{-1}=1.1209 \mathrm{~kg} \cdot \mathrm{ha}^{-1}, 1 \mathrm{oz} \cdot \mathrm{a}^{-1}=70 \mathrm{~g} \cdot \mathrm{ha}^{-1}$. ${ }^{5}$ Mean separation for each column using least significant difference at $P<0.05$.

Table 5. Plant height in mid Nov of winter wheat cultivars Goodstreak and Wesley planted at three dates with seed treated with water or gibberellic acid $\left(\mathrm{GA}_{3}\right)$ in 2006-07, 2007-08 and 2008-09.

\begin{tabular}{|c|c|c|c|c|c|c|c|c|c|}
\hline \multirow{3}{*}{$\begin{array}{c}\text { Planting } \\
\text { date }\end{array}$} & \multirow{3}{*}{$\begin{array}{l}\mathrm{GA}_{3}{ }^{1} \\
\mathrm{ppm}^{2}\end{array}$} & \multicolumn{4}{|c|}{ "Goodstreak" } & \multicolumn{4}{|c|}{ "Wesley” } \\
\hline & & 2006 & 2007 & 2008 & Mean & 2006 & 2007 & 2008 & Mean \\
\hline & & \multicolumn{7}{|c|}{ Plant height ${ }^{3}, \mathrm{~cm}$} & \\
\hline \multirow[t]{5}{*}{ mid Sep ${ }^{4}$} & 0 & 11.3 & 16.5 & 13.7 & 13.7 & 15.6 & 19.4 & 16.0 & 16.9 \\
\hline & 125 & 12.8 & 16.6 & 13.7 & 14.3 & 16.7 & 18.9 & 15.4 & 17.0 \\
\hline & 250 & 13.1 & 16.7 & 14.1 & 14.5 & 17.9 & 20.2 & 16.3 & 18.1 \\
\hline & 500 & 14.2 & 20.1 & 14.3 & 16.1 & 19.8 & 20.1 & 16.9 & 19.0 \\
\hline & 1000 & 15.8 & 22.7 & 17.6 & 18.5 & 21.2 & 22.6 & 19.7 & 21.2 \\
\hline \multirow[t]{5}{*}{ early Oct } & 0 & 8.3 & 11.0 & 8.6 & 9.2 & 9.4 & 13.1 & 10.2 & 10.8 \\
\hline & 125 & 10.9 & 12.6 & 9.6 & 11.0 & 10.3 & 13.4 & 10.2 & 11.3 \\
\hline & 250 & 13.1 & 15.6 & 11.6 & 13.4 & 12.0 & 14.5 & 11.5 & 12.6 \\
\hline & 500 & 16.1 & 17.9 & 13.7 & 15.9 & 14.0 & 15.1 & 13.0 & 14.0 \\
\hline & 1000 & 16.8 & 20.3 & 16.6 & 17.7 & 15.6 & 17.8 & 16.0 & 16.4 \\
\hline \multirow[t]{5}{*}{ mid Oct } & 0 & 4.5 & 6.7 & 6.7 & 5.9 & 5.3 & 7.5 & 6.9 & 6.5 \\
\hline & 125 & 5.7 & 7.8 & 8.1 & 7.1 & 6.2 & 7.9 & 7.3 & 7.1 \\
\hline & 250 & 6.8 & 9.7 & 8.4 & 8.0 & 7.1 & 8.6 & 8.3 & 7.9 \\
\hline & 500 & 7.5 & 10.3 & 10.0 & 9.1 & 7.2 & 9.4 & 8.7 & 8.3 \\
\hline & 1000 & 8.2 & 12.0 & 11.0 & 10.3 & 7.8 & 10.4 & 9.4 & 9.1 \\
\hline \multicolumn{2}{|c|}{ LSD 0.05} & 2.0 & 1.3 & 1.7 & 1.2 & 1.5 & 1.3 & 1.2 & 1.2 \\
\hline \multicolumn{2}{|c|}{$\mathrm{GA}_{3}$ treatment $(\mathrm{G})$} & $* * * 5$ & $* * *$ & $* * *$ & $* * *$ & *** & $* * * *$ & $* * *$ & $* * *$ \\
\hline \multicolumn{2}{|c|}{ Planting date (P) } & $* * *$ & $* * *$ & $* * *$ & $* * *$ & $* * *$ & $* * *$ & $* * *$ & $* * *$ \\
\hline \multicolumn{2}{|c|}{$\mathrm{G}^{*} \mathrm{P}$} & $*$ & $* * *$ & $* *$ & $* * *$ & $*$ & ns & $* *$ & $* * *$ \\
\hline
\end{tabular}

${ }^{1}$ Seeds were dipped in water or $\mathrm{GA}_{3}$ for 1 to $2 \mathrm{~min}$, air-dried for a week, and then planted. ${ }^{2} 1 \mathrm{inch}=2.54 \mathrm{~cm}, 1 \mathrm{lb} \cdot \mathrm{a}^{-1}=1.1209 \mathrm{~kg} \cdot \mathrm{ha}{ }^{-1}, 1 \mathrm{ppm}=1$ $\mathrm{mg} \cdot \mathrm{L}^{-1} .{ }^{3}$ Plant height was measured from ground to the highest leaf tip, and were measured on 20 Nov 06, 13 Nov 07 , and 19 Nov 08 . ${ }^{4}$ Planting dates were: 20 Sep 06, 18 Sep 07, and 18 Sep 08 for mid Sep; 4 Oct 06, 2 Oct 07, and 2 Oct 08 for early Oct, and 16 Oct 06 , 12 Oct 07 , and 15 Oct 08 for mid Oct. ${ }^{5} \mathrm{~ns}=$ not significant at $P<0.05 ;{ }^{*},{ }^{* * *},{ }^{* * *}=$ significant at $P<0.05, P<0.01$, and $P<0.001$, respectively.

in mid Oct to attain the same growth as untreated ones planted two weeks earlier. The situation was similar with Wesley except that 1000 ppm $\mathrm{GA}_{3}$ was needed for the seedlings planted later to compensate for the two weeks lost time (Table 5). Measuring plant height after winter, late March to harvest in July, there was little effect by $\mathrm{GA}_{3}$ on either cultivar (Table 6). Delaying planting significantly shortened plants in spring but there were no differences in the final plant height (Table 6). Plant weights were taken in mid spring which showed that these were slightly depressed by $\mathrm{GA}_{3}$. However, planting date had a more pronounced effect with plants having less weight with later planting (Table 7). Yields were not affected by $\mathrm{GA}_{3}$ and did not significantly differ between mid Sep and early Oct planting. A main concerns of late planting of winter wheat is that there would not be a 
Table 6. Post-winter plant height of winter wheat cultivars Goodstreak and Wesley planted at three dates with seed treated with water or gibberellic acid (GA $)$, mean of 2006-07, 2007-08 and 2008-09.

\begin{tabular}{|c|c|c|c|c|c|c|c|}
\hline \multirow{3}{*}{$\begin{array}{c}\text { Planting } \\
\text { date }\end{array}$} & \multirow{3}{*}{$\begin{array}{l}\mathrm{GA}_{3}{ }^{1} \\
\mathrm{ppm}^{3}\end{array}$} & \multicolumn{3}{|c|}{ "Goodstreak" } & \multicolumn{3}{|c|}{ "Wesley" } \\
\hline & & Early spring ${ }^{2}$ & Mid spring & Pre-harvest & Early spring & Mid spring & Pre-harvest \\
\hline & & \multicolumn{6}{|c|}{ Plant height ${ }^{4}, \mathrm{~cm}$} \\
\hline \multirow[t]{5}{*}{ mid Sep ${ }^{5}$} & 0 & 12 & 50 & 87 & 15 & 48 & 74 \\
\hline & 125 & 12 & 49 & 85 & 15 & 48 & 73 \\
\hline & 250 & 12 & 50 & 85 & 15 & 47 & 71 \\
\hline & 500 & 12 & 46 & 85 & 15 & 47 & 72 \\
\hline & 1000 & 12 & 47 & 87 & 15 & 44 & 69 \\
\hline \multirow[t]{5}{*}{ early Oct } & 0 & 9 & 50 & 87 & 11 & 44 & 69 \\
\hline & 125 & 9 & 48 & 85 & 11 & 45 & 70 \\
\hline & 250 & 9 & 47 & 85 & 11 & 43 & 67 \\
\hline & 500 & 10 & 46 & 86 & 12 & 43 & 68 \\
\hline & 1000 & 10 & 42 & 87 & 12 & 42 & 66 \\
\hline \multirow[t]{5}{*}{ early Oct } & 0 & 7 & 38 & 86 & 9 & 41 & 68 \\
\hline & 125 & 8 & 39 & 86 & 9 & 41 & 68 \\
\hline & 250 & 8 & 38 & 86 & 9 & 41 & 67 \\
\hline & 500 & 9 & 36 & 87 & 9 & 39 & 67 \\
\hline & 1000 & 8 & 36 & 90 & 10 & 37 & 66 \\
\hline \multicolumn{2}{|c|}{ LSD 0.05} & 1 & 4 & - & 1 & 3 & 5 \\
\hline \multicolumn{2}{|c|}{$\mathrm{GA}_{3}$ treatment $(\mathrm{G})$} & $* * * 6$ & $* * *$ & ns & $* * *$ & $* * *$ & ns \\
\hline \multicolumn{2}{|c|}{ Planting date (P) } & ${ }^{* * *}$ & ${ }^{* * *}$ & ns & $* * *$ & $* * *$ & ${ }^{* * *}$ \\
\hline \multicolumn{2}{|c|}{$\mathrm{G}^{*} \mathrm{P}$} & ns & ns & ns & ns & ns & ns \\
\hline
\end{tabular}

${ }^{1}$ Seeds were dipped in water or $\mathrm{GA}_{3}$ for 1 to 2 min, air-dried for a week, and then planted. ${ }^{2}$ Plant height was measured on 20 Mar 07 , 24 Mar 08 , and 8 Apr 09 (early spring readings); on 7 May 07, 19 May 08, and 22 May 09 (mid spring readings), and on 5 Jul 07, 17 Jul 08, and 16 Jul 09 (pre-harvest readings). ${ }^{3} 1$ inch $=2.54 \mathrm{~cm}, 1 \mathrm{lb} \cdot \mathrm{a}^{-1}=1.1209 \mathrm{~kg} \cdot \mathrm{ha}^{-1}, 1 \mathrm{ppm}=1 \mathrm{mg} \cdot \mathrm{L}^{-1}$. ${ }^{4}$ Plant height was measured from ground to the highest leaf tip. ${ }^{5} \mathrm{Planting}$ dates were: 20 Sep 06, 18 Sep 07, and 18 Sep 08 for mid Sep; 4 Oct 06, 2 Oct 07, and 2 Oct 08 for early Oct, and 16 Oct 06 , 12 Oct 07 , and 15 Oct 08 for mid Oct. ${ }^{6} \mathrm{~ns}=$ not significant at $P<0.05 ;{ }^{*},{ }^{* *},{ }^{* * *}=$ significant at $P<0.05, P<0.01$, and $P<0.001$, respectively.

sufficiently tall plant to reduce soil erosion [5] and this would reduce yield. These experiments did not show a yield effect concerning planting date because of small plot size. In large scale studies and in farmer's fields, such yield reductions due to soil erosion are routinely observed. Planting in mid Oct did have significantly less yield of Goodstreak than the earlier planting (Table 7). Wesley was not affected as much. There was no difference in germination of harvested seed between planting dates or $\mathrm{GA}_{3}$ rates (Table 7).

\subsection{Addition of 6BA to $\mathrm{GA}_{3}$ (2009 and 2010)}

In the 2009 planted trials, 6BA, a cytokinin, was added at 125, 500 and $2000 \mathrm{ppm}$ to $\mathrm{GA}_{3}$ at 500 and $1000 \mathrm{ppm}$ to Goodstreak and Wesley, respectively. 6BA-GA $\mathrm{G}_{3}$ mixtures were applied to seeds. As observed earlier, these $\mathrm{GA}_{3}$ rates increased plant height in November and had no significant effect on spring biomass, tiller number or yield (Table 8). Adding 6BA at 125 and $500 \mathrm{ppm}$ had no effect but $2000 \mathrm{ppm}$ had a deleterious effect on height compared to $\mathrm{GA}_{3}$ alone, on plant weight compared to untreated, and on grain yield (Table 8). Later planting dates, as observed previously, also had a depressing effect. Due to the negative effect of 6BA, in 2010, lower $6 \mathrm{BA}$ and $\mathrm{GA}_{3}$ concentrations were applied. 6BA at 31, 62 and $125 \mathrm{ppm}$ were added to $250 \mathrm{ppm}$ for Goodstreak and $500 \mathrm{ppm}$ for Wesley. At these rates, $\mathrm{GA}_{3}$ with or without 6BA had no effect at the recommended planting date (Table 9). At the two later planting dates, $\mathrm{GA}_{3}$ had a promotive effect on height but 6BA had no effect in addition to that of $\mathrm{GA}_{3}$ alone (Table 9). Notably, there was no promotion of tiller formation by 6BA, the rationale for its addition.

\subsection{Rye Response to $\mathrm{GA}_{3}$ (2007 and 2008)}

In a preliminary trial on rye cv. Rymin planted in 2006, $\mathrm{GA}_{3}$ applied at 1000 and $4000 \mathrm{ppm}$ to seed stimulated November height of plants seeded in October (data not shown). In 2007 and 2008 planted trials, rye was treated 
Table 7. Plant weight, yield and seed germination of winter wheat cultivars Goodstreak and Wesley planted at three dates with seed treated with water or gibberellic acid $\left(\mathrm{GA}_{3}\right)$, mean of 2006-07, 2007-08 and 2008-09.

\begin{tabular}{|c|c|c|c|c|c|c|c|c|c|}
\hline \multirow{3}{*}{$\begin{array}{c}\text { Planting } \\
\text { date }\end{array}$} & \multirow{3}{*}{$\begin{array}{l}\mathrm{GA}_{3}{ }^{1} \\
\mathrm{ppm}^{5}\end{array}$} & \multicolumn{4}{|c|}{ "Goodstreak" } & \multicolumn{4}{|c|}{ "Wesley” } \\
\hline & & Fresh weight ${ }^{2}$ & Dry weight & Yield $^{3}$ & Germination $^{4}$ & Fresh weight & Dry weight & Yield & Germination \\
\hline & & $\mathrm{kg} \cdot \mathrm{m}^{-2}$ & $\mathrm{~kg} \cdot \mathrm{m}^{-2}$ & $\mathrm{mg} \cdot \mathrm{ha}^{-1}$ & $\%$ & $\mathrm{~kg} \cdot \mathrm{m}^{-2}$ & $\mathrm{~kg} \cdot \mathrm{m}^{-2}$ & $\mathrm{mg} \cdot \mathrm{ha}^{-1}$ & $\%$ \\
\hline \multirow[t]{5}{*}{ mid Sep ${ }^{6}$} & 0 & 2.05 & 0.56 & 4.40 & 93 & 2.60 & 0.69 & 5.27 & 90 \\
\hline & 125 & 2.10 & 0.61 & 4.51 & 95 & 2.45 & 0.66 & 5.11 & 89 \\
\hline & 250 & 1.91 & 0.54 & 4.48 & 94 & 2.61 & 0.71 & 4.73 & 92 \\
\hline & 500 & 1.98 & 0.55 & 4.27 & 95 & 2.50 & 0.66 & 5.22 & 91 \\
\hline & 1000 & 1.86 & 0.51 & 4.25 & 95 & 2.50 & 0.67 & 4.66 & 91 \\
\hline \multirow[t]{5}{*}{ early Oct } & 0 & 1.77 & 0.51 & 4.77 & 95 & 2.11 & 0.56 & 5.03 & 90 \\
\hline & 125 & 1.71 & 0.49 & 4.79 & 96 & 2.11 & 0.56 & 5.14 & 89 \\
\hline & 250 & 1.69 & 0.47 & 4.73 & 94 & 2.14 & 0.55 & 4.88 & 90 \\
\hline & 500 & 1.79 & 0.47 & 4.75 & 95 & 2.17 & 0.58 & 4.85 & 90 \\
\hline & 1000 & 1.58 & 0.42 & 4.63 & 96 & 1.97 & 0.53 & 4.68 & 89 \\
\hline \multirow[t]{5}{*}{ early Oct } & 0 & 1.33 & 0.36 & 4.09 & 95 & 1.56 & 0.40 & 4.79 & 91 \\
\hline & 125 & 1.33 & 0.37 & 4.01 & 96 & 1.47 & 0.41 & 4.74 & 90 \\
\hline & 250 & 1.29 & 0.36 & 4.00 & 96 & 1.53 & 0.41 & 4.49 & 90 \\
\hline & 500 & 1.21 & 0.33 & 3.72 & 96 & 1.45 & 0.40 & 4.40 & 90 \\
\hline & 1000 & 1.02 & 0.28 & 3.59 & 96 & 1.35 & 0.35 & 4.13 & 90 \\
\hline \multicolumn{2}{|c|}{ LSD 0.05} & 0.25 & 0.07 & 0.51 & - & 0.24 & 0.07 & 0.69 & - \\
\hline \multicolumn{2}{|c|}{$\mathrm{GA}_{3}$ treatment $(\mathrm{G})$} & ${ }^{* 7}$ & ${ }^{* * *}$ & ns & ns & ns & ns & $*$ & ns \\
\hline \multicolumn{2}{|c|}{ Planting date (P) } & ${ }^{* * *}$ & ${ }^{* * *}$ & ${ }^{* * *}$ & ns & $* * *$ & ${ }^{* * *}$ & ${ }^{* *}$ & ns \\
\hline \multicolumn{2}{|c|}{$G^{*} P$} & ns & ns & ns & ns & ns & ns & ns & ns \\
\hline
\end{tabular}

${ }^{1}$ Seeds were dipped in water or $\mathrm{GA}_{3}$ for 1 to 2 min, air-dried for a week, and then planted. ${ }^{2}$ Plant weights (fresh and dry) were measured on 7 May 07 , 19 May 08, and 22 May 09 from a sample area of $0.5574 \mathrm{~m}^{+2}$ from each plot. ${ }^{3}$ Grain yield was harvested on $12 \mathrm{Jul} 07$, $24 \mathrm{Jul} 08$, and $30 \mathrm{Jul} 09 \mathrm{from}$ a plot area of $7.5 \mathrm{~m}^{2} .{ }^{4}$ Germination was determined from seeds sampled from the harvest of each plot only in $2009 .{ }^{5} 1 \mathrm{inch}=2.54 \mathrm{~cm}, 1 \mathrm{lb} \cdot \mathrm{a}^{-1}=1.1209$ $\mathrm{kg} \cdot \mathrm{ha}^{-1}, 1 \mathrm{ppm}=1 \mathrm{mg} \cdot \mathrm{L}^{-1}$. ${ }^{6}$ Planting dates were: 20 Sep 06, 18 Sep 07, and 18 Sep 08 for mid Sep; 4 Oct 06, 2 Oct 07, and 2 Oct 08 for early Oct, and 16 Oct 06,12 Oct 07 , and 15 Oct 08 for mid Oct. ${ }^{7}$ ns $=$ not significant at $P<0.05 ;^{*},{ }^{* *},{ }^{* * *}=$ significant at $P<0.05, P<0.01$, and $P<0.001$, respectively.

at the same rates of $\mathrm{GA}_{3}$ and planted on the same days as wheat. November heights of Rymin were increased by the $\mathrm{GA}_{3}$ application at the early and mid Oct plantings (Table 10). Between 250 and 1000 ppm GA 3 was sufficient to overcome the two-week delay in growth resulting from each 2-week delay in planting. In post winter height and weight measurements, there was no $\mathrm{GA}_{3}$ promotion although later planting date did reduce height and weight in the spring (Table 10). Rye was not taken to harvest since its use is as a cover crop into which summer crops such as potato are planted.

\section{Discussion}

\subsection{Application Methods}

In earlier studies on applying $\mathrm{GA}_{3}$ to wheat to stimulate stem or coleoptile elongation, the hormone was added to hydroponic solutions [21], injected weekly into the plant [22], soaked into germination paper [23], or applied to greenhouse soil to saturation [24]. These were greenhouse or growth chamber studies and would not be practical in a field situation or commercial use. In early 2005 [9], a growth chamber study on wheat indicated that direct seed and furrow applications of $\mathrm{GA}_{3}$ could stimulate stem growth of several cultivars. Using this information, the study was continued under field conditions. There was a significant November height response for Wesley to $\mathrm{GA}_{3}$ but there was no significant difference between direct application to seeds via a 2-min-dip or a spray. A furrow application of $\mathrm{GA}_{3}$ on Wesley likewise showed a response. Significant height promotion was achieved with $700 \mathrm{~g} \cdot \mathrm{ha}^{-1}$. With $\mathrm{GA}_{3}$ at US\$ $1.15 / \mathrm{g}$, the cost would be an exorbitant US\$ 800/ha or US\$ 325/a which is economically infeasible and further study on furrow application was discontinued. 
Table 8. Plant height on 17 Nov 09, fresh weight on 18 May 10, tiller number on 21 May 10, and yield on 28 July 10 of winter wheat cultivars Goodstreak and Wesley planted at three dates with seed treated with water, gibberellic acid (GA $\left.{ }_{3}\right)$ or $\mathrm{GA}_{3}$ plus 6-benzyl adenine (6BA) in 2009-10.

\begin{tabular}{|c|c|c|c|c|c|c|c|c|c|}
\hline \multirow[b]{2}{*}{$\mathrm{GA}_{3}{ }^{1}$} & \multirow[b]{2}{*}{$6 \mathrm{BA}$} & \multicolumn{4}{|c|}{ Goodstreak } & \multicolumn{4}{|c|}{ Wesley } \\
\hline & & Height $^{2}$ & Weight & Tiller & Yield & Height & Weight & Tiller & Yield \\
\hline $\mathrm{ppm}^{3}$ & ppm & $\mathrm{cm}$ & $\mathrm{kg} \cdot \mathrm{m}^{-2}$ & \#/plant & $\mathrm{mg} \cdot \mathrm{ha}^{-1}$ & $\mathrm{~cm}$ & $\mathrm{~kg} \cdot \mathrm{m}^{-2}$ & \#/plant & $\mathrm{mg} \cdot \mathrm{ha}^{-1}$ \\
\hline \multicolumn{10}{|c|}{17 Sep 09 planting } \\
\hline 0 & 0 & 9.1 & 1.96 & 5.8 & 3.75 & 10.1 & 1.62 & 5.4 & 4.18 \\
\hline 4 & 0 & 14.1 & 1.86 & 5.6 & 3.56 & 14.2 & 2.14 & 5.6 & 4.60 \\
\hline 4 & 125 & 15.1 & 1.76 & 8.3 & 3.65 & 14.9 & 1.92 & 4.8 & 4.45 \\
\hline 4 & 500 & 13.7 & 1.65 & 7.5 & 3.48 & 14.2 & 1.66 & 5.4 & 4.22 \\
\hline 4 & 2000 & 10.1 & 1.12 & 6.1 & 2.88 & 9.6 & 0.67 & 6.4 & 1.73 \\
\hline \multicolumn{10}{|c|}{30 Sep 09 planting } \\
\hline 0 & 0 & 6.4 & 1.88 & 4.1 & 3.63 & 6.8 & 1.35 & 5.6 & 4.32 \\
\hline 4 & 0 & 10.7 & 1.63 & 4.9 & 3.58 & 11.1 & 1.20 & 4.8 & 3.98 \\
\hline 4 & 125 & 11.3 & 1.56 & 5.7 & 3.39 & 11.6 & 1.44 & 4.6 & 3.95 \\
\hline 4 & 500 & 10.2 & 1.43 & 5.6 & 3.29 & 10.5 & 1.06 & 5.4 & 3.92 \\
\hline 4 & 2000 & 8.0 & 0.82 & 6.0 & 2.82 & 6.6 & 0.17 & 6.6 & 1.41 \\
\hline \multicolumn{10}{|c|}{19 Oct 09 planting } \\
\hline 0 & 0 & 1.9 & 1.10 & 4.2 & 2.66 & 2.0 & 1.00 & 6.3 & 3.72 \\
\hline 4 & 0 & 3.5 & 0.55 & 5.2 & 2.21 & 3.6 & 0.58 & 5.5 & 2.84 \\
\hline 4 & 125 & 3.8 & 0.67 & 5.3 & 2.66 & 3.6 & 0.50 & 5.6 & 2.55 \\
\hline 4 & 500 & 3.6 & 0.43 & 5.6 & 2.56 & 3.4 & 0.22 & 7.1 & 1.79 \\
\hline 4 & 2000 & 2.3 & 0.13 & 5.0 & 1.71 & 1.6 & - & 0 & 0.33 \\
\hline \multicolumn{2}{|c|}{ LSD0.05 } & 1.2 & 0.41 & - & 0.92 & 1.7 & 0.55 & 2.5 & 0.69 \\
\hline \multicolumn{2}{|c|}{ Treatment (T) } & $* * * 5$ & ${ }^{* * *}$ & ns & * & $* * *$ & ${ }^{* * *}$ & ns & $* * *$ \\
\hline \multicolumn{2}{|c|}{ Plant date (P) } & ${ }^{* * *}$ & $* * *$ & $*$ & $* * *$ & $* * *$ & $* * *$ & ns & $* * *$ \\
\hline \multicolumn{2}{|c|}{$\mathrm{T}^{*} \mathrm{P}$} & $* * *$ & ns & $\mathrm{ns}$ & ns & $* *$ & $* *$ & ns & $*$ \\
\hline
\end{tabular}

${ }^{1}$ Seeds were dipped in water, $\mathrm{GA}_{3}$, or $\mathrm{GA}_{3}+6 \mathrm{BA}$ for 1 to $2 \mathrm{~min}$, air-dried for a week, and then planted. ${ }^{2}$ Height was measured from ground to the highest leaf tip; weight was the fresh weight of plants in a sample area of $0.5574 \mathrm{~m}^{+2}$ in each plot, and tiller number was determined on four plants per plot. ${ }^{3} 1$ inch $=2.54 \mathrm{~cm}, 1 \mathrm{lb} \cdot \mathrm{a}^{-1}=1.1209 \mathrm{~kg} \cdot \mathrm{ha}^{-1}, 1 \mathrm{ppm}=1 \mathrm{mg} \cdot \mathrm{L}^{-1}$. ${ }^{4}$ The $\mathrm{GA}_{3}$ concentration used for "Goodstreak" was $500 \mathrm{ppm}$ and for "Wesley" was 1000 ppm. ${ }^{5} \mathrm{~ns}=$ not significant at $P<0.05 ;{ }^{*},{ }^{* * *},{ }^{* * *}=$ significant at $P<0.05, P<0.01$, and $P<0.001$, respectively.

\subsection{Planting Date Comparisons}

The preliminary trial in 2005 comparing three planting dates suggested that 1000 ppm GA 3 applied to Goodstreak or Wesley and planted later than mid Sep could stimulate November growth. There was no effect observed in spring and summer. A more detailed trial was conducted in 2006, 2007, and 2008. In Goodstreak, a significant $\mathrm{GA}_{3}$ rate response was observed regardless of planting date and more importantly $\mathrm{GA}_{3}$ application to seed overcame the lower growth resulting from planting two weeks later. For example, compare mean November height of 250 ppm treated Goodstreak planted in early October to untreated Goodstreak planted in mid Sep (Table 5). Making the same comparison on Wesley showed that this occurred but 1000 ppm $\mathrm{GA}_{3}$ was needed (Table 5). The data indicated that although Wesley was responsive, it required a higher $\mathrm{GA}_{3}$ concentration than Goodstreak, supporting growth chamber findings [9], and studies on cultivar responses and the genetics of dwarfing [22]-[24]. A probable, partial explanation for the difference in $\mathrm{GA}_{3}$ sensitivity between these two cultivars is that Wesley has the Rht8c and the Rht-B1b genes making it a semi-dwarf with limited endogenous $\mathrm{GA}_{3}$ and sensitivity to applied $\mathrm{GA}_{3}$ [15]. Comparing various wheat cultivars, Alan et al. [25] concluded that slow-emerging wheat cultivars were stimulated to emerge at the same rate as rapid-emerging ones when seeds were soaked for 4 hours with 200 ppm GA $\mathrm{GA}_{3}$. Lower soil temperatures from later planting can slow emergence as well and may be at least partially overcome by $\mathrm{GA}_{3}$ [24]. The results of this study demonstrated a use of $\mathrm{GA}_{3}$ seed application for late planting due to dry weather [4], fit into summer crop rotation or due to some delay in wheat planting. The relative response between Goodstreak and Wesley wheats to $\mathrm{GA}_{3}$ may be analogous to that 
Table 9. Plant height on 22 Nov 10, and fresh weight and tiller number on 10 May 11 of winter wheat cultivars Goodstreak and Wesley planted at three dates with seed treated with water, gibberellic acid $\left(\mathrm{GA}_{3}\right)$ or $\mathrm{GA}_{3}$ plus 6-benzyl adenine (6BA) in 2010-11.

\begin{tabular}{|c|c|c|c|c|c|c|c|c|}
\hline \multirow[b]{2}{*}{$\begin{array}{l}\text { Planting } \\
\text { date }\end{array}$} & \multirow[b]{2}{*}{$\begin{array}{l}\mathrm{GA}_{3}{ }^{1} \\
\mathrm{ppm}^{3}\end{array}$} & \multirow[b]{2}{*}{$\begin{array}{l}\text { 6BA } \\
\mathrm{ppm}\end{array}$} & \multicolumn{3}{|c|}{ Goodstreak } & \multicolumn{3}{|c|}{ Wesley } \\
\hline & & & $\begin{array}{l}\text { Height }^{2} \\
\mathrm{~cm}\end{array}$ & $\begin{array}{l}\text { Weight } \\
\mathrm{kg} \cdot \mathrm{m}^{-2}\end{array}$ & $\begin{array}{c}\text { Tiller } \\
\text { \#/plant }\end{array}$ & $\begin{array}{c}\text { Height } \\
\mathrm{cm}\end{array}$ & $\begin{array}{l}\text { Weight } \\
\mathrm{kg} \cdot \mathrm{m}^{-2}\end{array}$ & $\begin{array}{c}\text { Tiller } \\
\text { \#/plant }\end{array}$ \\
\hline \multirow[t]{5}{*}{17 Sep 10} & 0 & 0 & 16.8 & 1.77 & 6.6 & 21.0 & 3.37 & 5.4 \\
\hline & 4 & 0 & 17.0 & 2.15 & 5.6 & 23.8 & 3.75 & 7.0 \\
\hline & 4 & 31 & 16.9 & 2.34 & 4.6 & 20.8 & 3.14 & 7.2 \\
\hline & 4 & 62 & 15.8 & 2.03 & 5.6 & 21.4 & 3.68 & 6.6 \\
\hline & 4 & 125 & 17.1 & 2.03 & 6.0 & 21.8 & 2.89 & 7.0 \\
\hline \multirow[t]{5}{*}{1 Oct 10} & 0 & 0 & 10.1 & 1.66 & 5.0 & 12.2 & 2.73 & 5.4 \\
\hline & 4 & 0 & 13.2 & 2.04 & 6.6 & 16.9 & 2.79 & 5.4 \\
\hline & 4 & 31 & 12.5 & 1.71 & 6.0 & 17.6 & 2.56 & 5.2 \\
\hline & 4 & 62 & 13.7 & 1.44 & 5.2 & 15.7 & 2.60 & 5.0 \\
\hline & 4 & 125 & 13.7 & 1.51 & 5.0 & 15.8 & 2.24 & 5.4 \\
\hline \multirow[t]{5}{*}{17 Oct 10} & 0 & 0 & 7.9 & 1.06 & 5.2 & 7.6 & 1.37 & 4.6 \\
\hline & 4 & 0 & 9.7 & 1.01 & 4.8 & 10.3 & 1.43 & 4.6 \\
\hline & 4 & 31 & 9.8 & 1.02 & 4.8 & 11.4 & 1.41 & 4.0 \\
\hline & 4 & 62 & 10.0 & 0.94 & 5.0 & 9.8 & 1.35 & 4.0 \\
\hline & 4 & 125 & 9.5 & 1.21 & 5.0 & 10.4 & 1.06 & 4.8 \\
\hline \multicolumn{3}{|c|}{ LSD 0.05} & 2.0 & 0.90 & - & 1.9 & 0.75 & 1.7 \\
\hline \multicolumn{3}{|c|}{ treatment $(\mathrm{T})$} & $* 5$ & ns & ns & ${ }^{* * *}$ & ns & ns \\
\hline \multicolumn{3}{|c|}{ Planting date (P) } & *** & *** & ${ }^{* * *}$ & $* * *$ & $* * *$ & ${ }^{* * *}$ \\
\hline \multicolumn{3}{|c|}{$\mathrm{T}^{*} \mathrm{P}$} & ns & ns & ns & $* *$ & ns & ns \\
\hline
\end{tabular}

${ }^{1}$ Seeds were dipped in water, $\mathrm{GA}_{3}$, or $\mathrm{GA}_{3}+6 \mathrm{BA}$ for 1 to 2 min, air-dried for a week, and then planted. ${ }^{2}$ Height was measured from ground to the highest leaf tip; weight was the fresh weight of plants in a sample area of $0.5574 \mathrm{~m}^{+2}$ in each plot, and tiller number was determined on four plants per plot. ${ }^{3} 1$ inch $=2.54 \mathrm{~cm}, 1 \mathrm{lb} \cdot \mathrm{a}^{-1}=1.1209 \mathrm{~kg} \cdot \mathrm{ha}^{-1}, 1 \mathrm{ppm}=1 \mathrm{mg} \cdot \mathrm{L}^{-1}$. "The $\mathrm{GA}_{3}$ concentration used for "Goodstreak" was $250 \mathrm{ppm}$ and for "Wesley" was 500 ppm. ${ }^{5} \mathrm{~ns}=$ not significant at $P<0.05 ;{ }^{*},{ }^{* *},{ }^{* * *}=$ significant at $P<0.05, P<0.01$, and $P<0.001$, respectively.

reported in field studies on common bean cultivars Matterhorn and Poncho where $\mathrm{GA}_{3}$ was applied to foliage to stimulate stem elongation for direct harvest [26]. In both studies, the elongation stimulation by $\mathrm{GA}_{3}$ was for a relatively short term.

Comparing the two wheat cultivars to the rye cultivar Rymin, it seems that Rymin was slightly less sensitive to $\mathrm{GA}_{3}$ than Goodstreak but more than Wesley. This agrees with the observation made using the growth chamber bioassay [9]. Since Rymin is moderately tall, this may indicate a correlation between plant height and seedling growth promotion by $\mathrm{GA}_{3}$ measured in late autumn.

\subsection{Addition of 6-Benzyl Adenine}

Since cytokinin growth regulators such as 6BA are known to promote bud break via stimulating cell division [27], there was the possibility that 6BA could promote tiller production in conjunction with the stem growth from $\mathrm{GA}_{3}$ application. However, as in the growth chamber study [8], 6BA had no beneficial effect and even had a deleterious effect when applied at high concentrations.

\section{Conclusions}

\subsection{Potential Use}

This study demonstrated that $\mathrm{GA}_{3}$ applied directly to seed would stimulate pre-winter seedling growth when

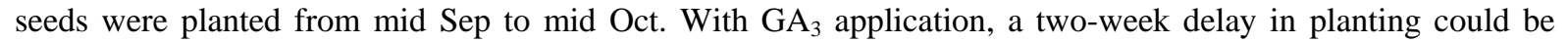
overcome. This would result in the plant size and stand to be sufficient to resist wind-induced soil erosion during the winter and stabilize the field even though the field was planted later than recommended. This would also 
Table 10. Plant heights and weights of the winter rye cultivar Rymin planted at three dates with seed treated with water or gibberellic acid $\left(\mathrm{GA}_{3}\right)$, mean of 2007-08 and 2008-09.

\begin{tabular}{|c|c|c|c|c|c|c|}
\hline \multirow[b]{2}{*}{$\begin{array}{c}\text { Planting } \\
\text { date }^{3}\end{array}$} & \multirow[b]{2}{*}{$\begin{array}{l}\mathrm{GA}_{3}{ }^{2} \\
\mathrm{ppm}^{4}\end{array}$} & \multicolumn{3}{|c|}{ Plant height ${ }^{1}$} & Fresh weight $^{1}$ & Dry weight \\
\hline & & November & $\begin{array}{c}\text { March/April } \\
\text { cm }\end{array}$ & May & \multicolumn{2}{|c|}{$\begin{array}{c}\text { May } \\
\mathrm{kg} \cdot \mathrm{m}^{-2}\end{array}$} \\
\hline \multirow[t]{5}{*}{ mid Sep } & 0 & 16.4 & 20.0 & 81 & 2.7 & 0.70 \\
\hline & 125 & 15.9 & 19.5 & 81 & 3.0 & 0.73 \\
\hline & 250 & 16.7 & 19.3 & 79 & 2.7 & 0.68 \\
\hline & 500 & 15.8 & 18.4 & 78 & 2.9 & 0.70 \\
\hline & 1000 & 16.9 & 17.1 & 80 & 2.8 & 0.69 \\
\hline \multirow[t]{5}{*}{ early Oct } & 0 & 10.9 & 14.4 & 78 & 2.5 & 0.63 \\
\hline & 125 & 11.5 & 13.5 & 79 & 2.6 & 0.62 \\
\hline & 250 & 12.4 & 13.9 & 76 & 2.5 & 0.65 \\
\hline & 500 & 13.7 & 13.3 & 75 & 2.5 & 0.63 \\
\hline & 1000 & 15.1 & 13.2 & 77 & 2.5 & 0.63 \\
\hline \multirow[t]{5}{*}{ early Oct } & 0 & 7.2 & 10.3 & 66 & 1.8 & 0.48 \\
\hline & 125 & 9.7 & 9.3 & 65 & 1.8 & 0.45 \\
\hline & 250 & 11.2 & 10.2 & 65 & 2.0 & 0.50 \\
\hline & 500 & 12.0 & 10.8 & 63 & 1.8 & 0.45 \\
\hline & 1000 & 12.5 & 10.4 & 61 & 1.7 & 0.43 \\
\hline \multicolumn{2}{|c|}{ LSD 0.05} & 1.1 & 1.5 & 4 & 0.3 & 0.07 \\
\hline \multicolumn{2}{|c|}{$\mathrm{GA}_{3}$ treatment $(\mathrm{G})$} & $* * * 5$ & ns & ns & ns & ns \\
\hline \multicolumn{2}{|c|}{ Planting date $(\mathrm{P})$} & $* * *$ & $* * *$ & $* * *$ & $* * *$ & $* * *$ \\
\hline \multicolumn{2}{|c|}{$\mathrm{G}^{*} \mathrm{P}$} & $* * *$ & ns & ns & ns & ns \\
\hline
\end{tabular}

${ }^{1}$ Plant heights were measured on 12 Nov 07 and 19 Nov 08 (pre-winter), on 20 Mar 08, and 8 Apr 09 (early spring), and on 16 May 08 and 18 May 09 ; plant weights were measured in May with last height measurements. ${ }^{2}$ Seeds were dipped in water or $\mathrm{GA}_{3}$ for 1 to 2 min, air-dried for a week, and then planted. ${ }^{3}$ Planting dates were: 18 Sep 07 and 18 Sep 08, 2 Oct 07 and 2 Oct 08 , and 12 Oct 07 and 15 Oct 08 . ${ }^{4} 1$ inch $=2.54 \mathrm{~cm}, 1 \mathrm{lb} \cdot \mathrm{a}^{-1}=1.1209$ $\mathrm{kg} \cdot \mathrm{ha}^{-1}, 1 \mathrm{ppm}=1 \mathrm{mg} \cdot \mathrm{L}^{-1} .{ }^{5} \mathrm{~ns}=$ not significant at $P<0.05 ;{ }^{* * *}=$ significant at $P<0.001$.

improve crop rotation when wheat is planted after a summer crop that is harvested in late September or early October. Furthermore, $\mathrm{GA}_{3}$ gives an additional production practice in case of adverse weather resulting in delayed planting. Note that there were differences between the two tested cultivars with respect to the amount of $\mathrm{GA}_{3}$ needed and the degree of response vis-a-vis planting dates. The differences in cultivar sensitivity to GA can be explained by the semi-dwarf character of the cultivars.

\subsection{Economic Considerations}

Considering its potential uses, applying $\mathrm{GA}_{3}$ to seed can be considered as an "insurance policy" but its cost needs to be considered as well. The following cost-estimate will be based on applying 1000 ppm GA 3 to Wesley. The product used in these studies was Release ${ }^{\odot}$ (Valent BioScience) which contains $33.8 \mathrm{~g} \cdot \mathrm{L}^{-1}$ (1 g per fl. oz). The non-discounted, retail price of US\$ 1.15 per $\mathrm{g} \mathrm{GA}_{3}$ results in a cost of US\$ $38.87 \mathrm{~L}^{-1}$. Therefore, 1 liter of a 1000 -ppm $\mathrm{GA}_{3}$ solution would cost US\$1.15. The label range for application onto wheat would include $\mathrm{GA}_{3}$ at $1.2 \mathrm{~g}$ in $1.2 \mathrm{~L}(1000 \mathrm{ppm})$ applied to $45 \mathrm{~kg}$ seed. The cost would be US\$ 1.38 per $45 \mathrm{~kg}$. In the studies planted in 2006, 2007 and 2008, $1.6 \mathrm{~kg}$ Wesley seed was treated with $1 \mathrm{~L}$ of solution via soaking. On a 45-kg basis, this would be equivalent to exposing seed to $28 \mathrm{~L}$ which would be impractical. Seed weights were taken before treatment and again after treatment when seeds had dried. Wesley seed gained about 2.5\% in weight indicating that about $25 \mathrm{~mL}$ of solution was absorbed per kg Wesley seed or about $555 \mathrm{~mL}$ per $45 \mathrm{~kg}$ which is within the labeled application range with a maximum of $591 \mathrm{~mL}$ for $45 \mathrm{~kg}$. Therefore, the laboratory application method should be translatable to practical field application. In working with Nebraska growers, the practical and inexpensive method of $\mathrm{GA}_{3}$ application is to apply the product with or without fungicides onto seed using a spray nozzle fitted atop of the auger on a wheat planter during the seeding operation. Several growers have reported to me that this has worked excellently and have made this a routine procedure in their operation. With a seeding 
rate $300 \mathrm{~m}^{-2}\left(3 \times 10^{-6} \mathrm{ha}^{-1}\right)$ and a seed weight of $3 \mathrm{~g}$ per 100 seeds, the weight of seed is $90 \mathrm{~kg} \cdot \mathrm{ha}^{-1}$. To treat 90 $\mathrm{kg}(200 \mathrm{lb})$ of Wesley seed with $1000 \mathrm{ppm} \mathrm{GA}$ would calculate to US\$2.76 ha ${ }^{-1}$ or US\$ $1.12 \mathrm{a}^{-1}$. These calculations and grower experiences indicate that on-farm $\mathrm{GA}_{3}$ seed application to wheat is an inexpensive "insurance policy" against delayed planting due to weather or harvesting of a rotational summer crop such as potato and common bean.

\section{Acknowledgements}

We thank Les Kampbell and Eric Nielsen for their technical assistance, and the financial support by the Nebraska Wheat Board, Nebraska Potato Development Committee, Nebraska Crop Improvement Association, and Valent BioScience Corp.

\section{References}

[1] USDA (1997) Usual Planting and Harvesting Dates for US Field Crops. Agriculture Handbook \# 628, National Agricultural Statistics Services, Washington DC.

[2] Schwartz, H.F., Brick, M.A., Harveson, R.M. and Franc, G.D., Eds. (2004) Dry Bean Production \& Integrated Pest Management. 2nd Edition, Colorado State University Regional Bulletin \#562A, Fort Collins.

[3] Pavlista. A.D. (1995) Potato Production Stages: Scheduling Key Practices. University of Nebraska Extension Circular \#1249, Lincoln. http://cropwatch.unl.edu/web/potato/key_production_stages

[4] Pavlista, A.D. and Santra, D.K. (2013) Planting Winter Wheat in Dry Soil. University of Nebraska NebGuide \#2211, Lincoln. www.ianrpubs.unl.edu/sendit/g2211.pdf

[5] Lyon, D.J. and Smith, J.A. (2010) Wind Erosion and Its Control. University of Nebraska NebGuide \#1537, Lincoln. www.ianrpubs.unl.edu/sendit/g1537.pdf

[6] Takahashi, N., Phinney, B.O. and MacMillan, J. (1991) Gibberellins. Springer-Verlag, New York. http://dx.doi.org/10.1007/978-1-4612-3002-1

[7] Davies, P.J. (2010) Plant Hormones: Biosynthesis, Signal Transduction, Action. 3rd Edition, Springer-Verlag, New York. http://dx.doi.org/10.1007/978-1-4020-2686-7

[8] Pavlista, A.D., Santra, D.K., Schild, J.A. and Hergert, G.W. (2012) Gibberellic Acid Sensitivity among Common Bean Cultivars (Phaseolus vulgaris L.). HortScience, 47, 637-642.

[9] Pavlista, A.D., Santra, D.K. and Baltensperger, D.D. (2013) Bioassay of Winter Wheat for Gibberellic Acid Sensitivity. American Journal of Plant Sciences, 4, 2015-2022. http://dx.doi.org/10.4236/ajps.2013.410252

[10] Busov, V.B., Brunner, A.M. and Strauss, S.H. (2008) Genes for Control of Plant Stature and Form. New Phytologist, 177, 589-607. http://dx.doi.org/10.1111/j.1469-8137.2007.02324.x

[11] Peng, J., Richards, D.E., Hartley, N.M., Murphy, G.P., Devos, K.M., Flintham, J.E., Beales, J., Fish, L.J., Worland, A. J., Pelica, F., Sudhakar, D., Christou, P., Snape, J.W., Gale, M.D. and Harberd, N.P. (1999) “Green Revolution” Genes Encode Mutant Gibberellin Response Modulator. Nature, 400, 256-261. http://dx.doi.org/10.1038/22307

[12] Baenziger, P.S., Beecher, B., Graybosch, R.A., Baltensperger, D.D., Nelson, L.A., Krall, J.M., McVey, D.V., Watkins, J.E., Hatchett, J.H. and Chen, M.S. (2004) Registration of “Goodstreak” Wheat. Crop Science, 44, 1473-1474. http://dx.doi.org/10.2135/cropsci2004.1473

[13] Peterson, C.J., Shelton, D.R., Baenziger, P.S., Baltensperger, D.D., Graybosch, R.A., Worrall, W.D., Nelson, L.A., McVey, D.V., Watkins, J.E. and Krall, J. (2001) Registration of “Wesley” Wheat. Crop Science, 41, 260-261. http://dx.doi.org/10.2135/cropsci2001.411260-ax

[14] Börner, A., Plaschke, J., Korzun, V. and Worland, A.J. (1996) The Relationships between the Dwarfing Genes of Wheat and Rye. Euphytica, 89, 69-75. http://dx.doi.org/10.1007/BF00015721

[15] Worland, A.J., Korzun, V., Röder, M.S., Ganal, M.W. and Law, C.N. (1998) Genetic Analysis of the Dwarfing Gene Rht8 in Wheat. Part II. The Distribution and Adaptive Significance of Allelic Variants at the Rht8 Locus of Wheat as Revealed by Microsatellite Screening. Theoretical and Applied Genetics, 96, 1110-1120. http://dx.doi.org/10.1007/s001220050846

[16] Snapp, S.S., Swinton, S.M., Labarta, R., Mutch, D., Black, J.R., Leep, R., Nyiraneza, J. and O’Neil, K. (2005) Evaluating Cover Crops for Benefits, Costs and Performance within Cropping System Niches. Agronomy Journal, 97, 322332.

[17] Oelke, E.A., Oplinger, E.S., Bahri, H., Durgan, B.R., Putnam, D.H., Doll, J.D. and Kelling, K.A. (1990) Rye. Alternative Crops Manual, University of Minnesota and Wisconsin, Madison. http://www.hort.purdue.edu/ 
[18] Robinson, R.G. (1973) Registration of Rymin Rye. Crop Science, 13, 775. http://dx.doi.org/10.2135/cropsci1973.0011183X001300060075x

[19] Changnon, S.A., Lamb, P. and Hubbard, K.G. (1990) Regional Climate Centers: New Institutions for Climate Services and Climate-Impact Research. Bulletin of the American Meteorological Society, 71, 527-537. http://dx.doi.org/10.1175/1520-0477(1990)071<0527:RCCNIF>2.0.CO;2

[20] Anonymous (2009) AOSA Rules for Testing Seeds: Vol. 1, Principles and Procedures. Association of Official Seed Analysts, Ithaca, New York.

[21] Gale, M.D. and Marshall, G.A. (1973) Insensitivity to Gibberellin in Dwarf Wheats. Annals of Botany, 37, 729-735.

[22] Allan, R.E., Vogel, O.A. and Craddock Jr., J.C. (1959) Comparative Response to Gibberellic Acid of Dwarf, Semidwarf, and Standard Short and Tall Winter Wheat Varieties. Agronomy Journal, 51, 737-740. http://dx.doi.org/10.2134/agronj1959.00021962005100120013x

[23] Pereira, M.J., Pfahler, P.L., Barnett, R.D., Blount, A.R., Wofford, D.S. and Littell, R.C. (2002) Coleoptile Length of Dwarf Wheat Isolines: Gibberellic Acid, Temperature, and Cultivar Interactions. Crop Science, 42, 1483-1487. http://dx.doi.org/10.2135/cropsci2002.1483

[24] Pinthus, M.J. and Abraham, M. (1996) Effects of Light, Temperature, Gibberellin (GA 3 ) and Their Interaction on Coleoptile and Leaf Elongation of Tall, Semi-Dwarf and Dwarf Wheat. Plant Growth Regulations, 18, 239-247. http://dx.doi.org/10.1007/BF00024388

[25] Allan, R.E., Vogel, O.A. and Craddock Jr., J.C. (1961) Effect of Gibberellic Acid upon Seedling Emergence of Slow and Fast Emerging Wheat Varieties. Agronomy Journal, 53, 30-32. http://dx.doi.org/10.2134/agronj1961.00021962005300010011x

[26] Pavlista, A.D., Hergert, G.W., Santra, D.K. and Schild, J.A. (2013) Improving Bean Harvest with Gibberellic Acid. HortTechnology, 23, 282-287.

[27] Mok, D.W.S. and Mok, M.C. (1994) Cytokinins: Chemistry, Activity, and Function. CRC Press, Boca Raton. 
Scientific Research Publishing (SCIRP) is one of the largest Open Access journal publishers. It is currently publishing more than 200 open access, online, peer-reviewed journals covering a wide range of academic disciplines. SCIRP serves the worldwide academic communities and contributes to the progress and application of science with its publication.

Other selected journals from SCIRP are listed as below. Submit your manuscript to us via either submit@scirp.org or Online Submission Portal.
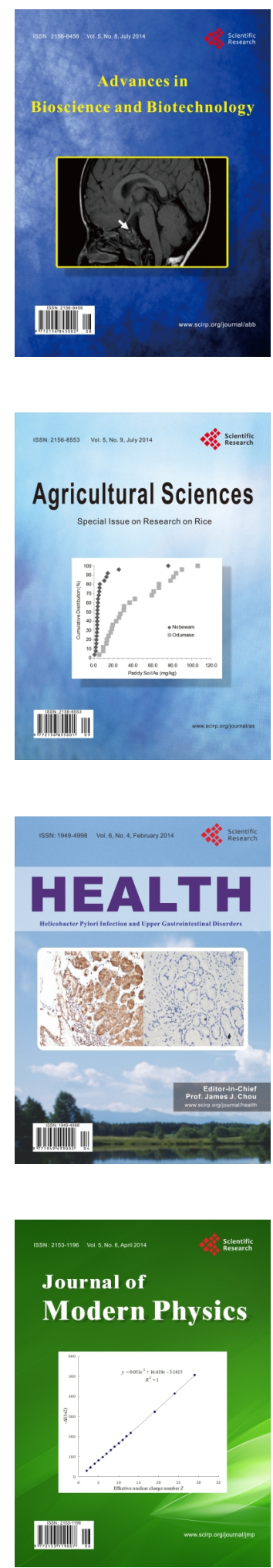
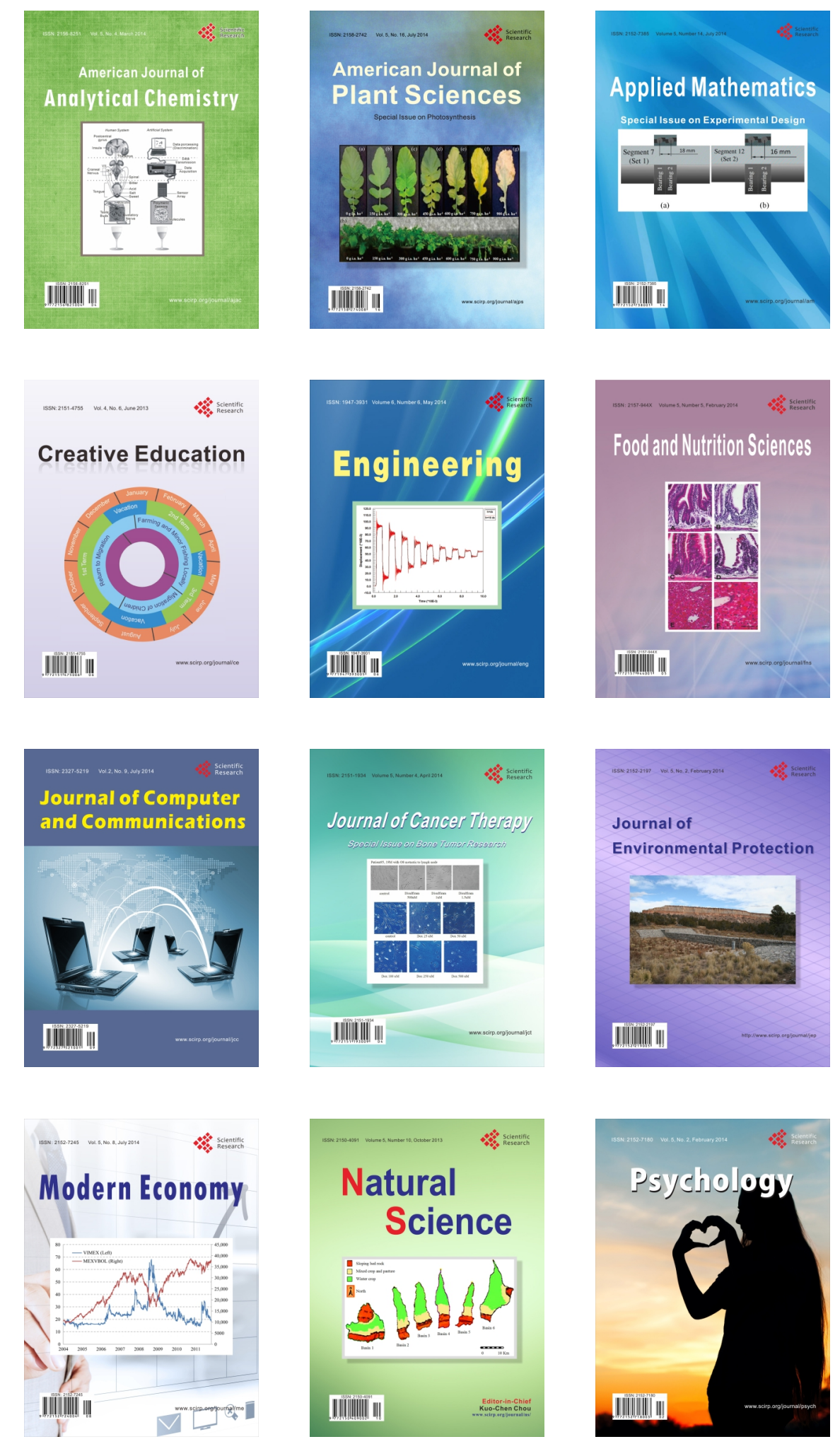